\title{
Type A Lymphomatoid Papulosis
}

National Cancer Institute

\section{Source}

National Cancer Institute. Type A Lymphomatoid Papulosis. NCI Thesaurus. Code C7197.

A variant of lymphomatoid papulosis characterized by the presence of scattered

anaplastic large lymphocytes, often resembling Reed-Sternberg cells, admixed with acute and chronic inflammatory cells. 